\title{
Becoming a Journalist in the World of Masculine Media: A Study of Gender Distinctions in Journalistic Work
}

\author{
Amelita Lusia $^{1 *}$, Devie Rahmawati ${ }^{2}$, Geger Riyanto ${ }^{3}$, Deddy Mulyana ${ }^{4}$, Adhita \\ Yukihana $^{5}$ \\ 1,2,5 Vocational Program, Communication Studies, Universitas Indonesia \\ ${ }^{3}$ Sociology Department, Universitas Indonesia \\ ${ }^{4}$ Faculty of Communication Sciences, Universitas Padjadjaran \\ *Email: amelitalusia@yahoo.com
}

\begin{abstract}
The working world is a field that is separated according to gender. In the imagination of some societies, for example, domestic work cannot be separated from women's gender while work in the public domain, remains the domain of men. In the context of such segregation, the work of media journalists whose work require contact with public affairs tends to be assigned to men. Although today there are a number of respected female journalists, women remain a segregated group of journalists. Against this background, this research examines women journalists life experiences managing and engaging with the ideological veil that structures media work. This research will explore these dynamics by examining the history and professional life of some female journalists.
\end{abstract}

Keywords: working world, media, gender separation, discrimination

\section{Introduction}

As with any occupation, working in a mass media organization can never be separated from gender distinctions. The media profession has been synonymous with men for a long time. The activities involved in researching the news, determining the issues, relating to sources, and some other tasks, are generally ascribed a masculine character.

This situation is applicable to many different countries. For example, a handbook edited by Byerly (2013) collected writings from media reviewers from a number of countries. Their findings on the position of women in the mass media, the main theme of this book, are oddly similar to each other. In both developed countries such as Britain, Japan, or Germany, and in those considered third-world countries such as Bangladesh, Mexico, or Uganda, women occupy a weak position in media organizations.

Indeed, there are some optimistic writers who are trying to argue that the status of female media workers in their country is more promising than the global position of female media workers. Bulgaria has claimed to be an exception. In this country, women occupy important positions at the editorial desk as decision makers. However, we think that we will still be able to detect a common pattern in the position of women in media crews. Despite the fact that a relative transformation has occurred in every country, women do not yet occupy as strong a position as men.

The different historical backgrounds and development trajectories in different countries cannot be denied. The global trend indicates a pattern that will lead either to the variation or the transformation of women's positions in media work. A transformation is taking place according to the articles collected in Byerly's books and in other studies. The number of women working in the media continues to grow, and this trend does not seem likely to lag in the near future.

Due to this trend, pessimism about the professional position of women in the media can be denied. The current world of work has changed considerably compared to the past, when the representation of women in professional positions was much less significant. The growth of women's representation in the mass media could potentially reduce the imbalance between men and women in the future. However, this development cannot be separated from developments in the world of work in general. Professional positions are increasingly occupied by women, but this does not necessarily mean that women enjoy an equal position to men. The so-called feminizing of the work place is essentially a consequence of an increasingly open labor market where the availability of female labor has led to the suppression of workers' wages (Comaroff \& Comaroff, 2001). 
Inclusion and exclusion certainly accompany women's deeper participation in the labor market. New norms are formed when more women participate in the public domain; yet more and more women are also the backbone of the family. However, the logic of this process ensures that workers continue to be available at a wage rate that increases profits for shareholders. Thus, work does not necessarily empower women, and in fact the reinforcement of patriarchal values may take place. As some of the authors complained in the book edited by Byerly, the number of women is not always directly proportional to the positions they occupy at the editorial table.

This paper examines this macro scale trend through the experience of being a female journalist in Indonesia. The data was collected by conducting qualitative research investigating women who work in Indonesian national mass media. The data was obtained through interviews with ten women journalists, and observations were made through continuous interaction with the media work environment. Does the Indonesian situation justify, challenge, or differ from the general trend? How is discrimination experienced in the daily life of women journalists in Indonesia? Furthermore, how is discrimination related to patriarchal values and the structure of capitalism in general?

\section{Literature Review}

This paper departs from the understanding that gender is selected in the domain of actors' comprehension that forms it, but is also varied by the practice they are performing in the actual domain. Gender distinguishes between men and women. The problem with this selection is that it isolates one group that has certain physical characteristics from the other group, and places them in an unstable position. This imbalance, in general, rests on the connotations carried by both groups, i.e. women are inherent to the domestic domain, are objects, and passive, while men are actors in the public domain, are subjects, and active.

John Berger's study of the long history of visual art in the West, for example, shows that women are always positioned as a beautiful object, in a mere pose to be painted. On the contrary, men are always painted in action, such as fighting, intrigue, negotiating, and so forth. Apparently, this study intersects with studies of the male gaze and is not a pure coincidence (Mulvey, 2009). The representation of women in various media, according to reviewers who examine this concept, is shaped by what men expect from women. Consequently, images of women that appear in harmony with patriarchal ideology dominated from the beginning. Although these images - as well as most of the images on which the theories of gender inequality are based on - only refer to the Western situation, in cross-cultural contexts, ethnographic findings consistently demonstrate that women do not occupy positions that are politically superior or equal to men (Rosaldo \& Lamphere, 1974).

This is also true in the professional world. However, it differs from the domestic domain or media representations where the final objective of women's subordination is the enforcement of ideology. The work domain is an environment that is highly conditioned by the capitalist principle of the accumulation of profit. Marx (1967) himself observed that the development of capitalism replaced skilled workers with unskilled workers, adult workers with child laborers, and male workers with female workers. The recruitment of women as laborers has enabled companies to reduce expenditure on wages.

Feminist theorists have used a Marxian perspective to explore gender-based inequality. A common presupposition is that the inclusion of women in contemporary labor structures leads capitalism and patriarchy to be mutually beneficial. Women have been exploited as workers to benefit company owners financially (Caraway, 2007). However, some simplifications occur when we assume that capitalism and patriarchy operate in an evil alliance that oppresses women.

The reality of the world of journalism is certainly more complex. However, we can at least gain the inspiration that in the professional domain practically the patriarchal ideology manifestation will always intersect with the principle of effectiveness. Occupation or work cannot be reduced to patriarchal ideology. Marshall Sahlins (1976) once noted that practical and cultural reasoning works in two separate but interconnected dimensions. Our understanding guides the practice of actors by adopting a dominant narrative. At the same time, however, a number of dramatic variations arise due to actual conditions that require resolution by certain actions.

Mockery in Office Surroundings Women are a minority in the Indonesian media. The exact number of female workers in the media has never been calculated. However, according to their lack of appearance in the field or editorial office, there are never as many as men, and the numbers of women who occupy strategic positions are not significant.

A number of female journalists we interviewed experienced different treatment from male journalists. One admitted that there were colleagues and superiors who considered male journalists more logical when 
reporting news. Nevertheless, some male reporters had positively recognized that female journalists were more thorough. Such male journalists also felt that female journalists were more assertive when supervising as editors.

The difficulties experienced by female journalists when covering news involved vying with male journalists whose postures were bigger and stronger when doorstopping (interviewing a resource person who has just left the room or building). During such moments, every journalist scrambles to get a closer position with the resource person. One female journalist admitted that such situations required her to be out of the crowd to concentrate on reporting on the speakers from a distance, then contact the informant personally for more information.

Beyond these physical barriers, the female journalists we interviewed did not perceive that fellow journalists influenced their professional position. This does not mean that interviews were free from negative remarks. However, such judgments never form a collective perception toward women who undermine their positions in this profession. Our observations indicated that a number of female journalists have a strategic position in the media. They occupy positions such as managing editor or chief editor. Many of them were also sent to conflict areas for more than a month.

What seemed to contribute to their minority position were expectations outside the work environment. Some of these female journalists experienced demands to allocate time for their family. However, journalism, unlike work in a number of other industries and sectors, does not follow a time schedule and takes a lot of time. Assignments can be appointed at any time, even in the middle of the night or early in the morning. Deadlines may require journalists not to return home until the job is completed. This is more of a burden for female journalists than male journalists. Frequently, we heard of female reporters resigning after getting married to devote their life to their family.

The demands of external factors have led to fewer female journalists. Meanwhile, the number of female applicants for media jobs is lower than males. Consequently, there are very few female journalists who are competent to occupy strategic positions. The lower representation of women in the journalist profession appears to be caused by external problems, rather than an ideological structure that perpetuates gender inequalities in editorial offices. However, undoubtedly, this issue cannot be separated from gender segregation, which places women in the domestic domain and men in the external domain.

The low number of female journalists also seems related to the image of journalists as very masculine. Journalism demands very intense contact with the public domain and people in positions of power and influence in public life. These figures are mostly men, therefore contact with journalists as equal parties reinforces the positioning of male journalists as well. In addition, particularly in Indonesia, journalists are regularly involved in rogue practices such as extortion and defamation. These negative practices are more likely to involve men than women.

Between Becoming an Object and Getting Respect We observed that women's minority position in media organizations is not directly influenced by the ideological bias of the work environment. However, these observations did not include harassment and women's treatment as objects during their daily activities. According to our findings, this form of discrimination is experienced by female journalists.

First, female journalists' facial beauty often determines their treatment by fellow journalists and resource people. A beautiful female journalist will usually attract attention and special treatment. They will be approached irrespective of their ability as journalists. In the world of journalists, they often become the object of resource people's attention. Resource people often ask to be interviewed outside the office. They also respond to journalists with seductive overtures. Some informants even ask to be interviewed at a hotel.

In addition, during moments that involve a crowd, journalists are also objects of abuse. This situation usually involves labor protests or doorstopping. However, most of our interview subjects said they were not harassed by their fellow journalists, while one female journalist admitted that they were some people who disguise themselves as journalists and try to take advantage of the situation. Although this was difficult for us to confirm, this statement at least shows that male journalists have a positive image in the eyes of female journalists. This seems reasonable considering personal reputation will always follow an individual in an environment where everyone knows each other, and consequently, it is important to maintain high esteem.

Some of the female journalists we interviewed also admitted that her male colleagues had a tendency to look after them. A female reporter confessed that male journalists protected female journalists who cover the news in difficult situations, such as conflict areas. One female journalist admitted that her superiors asked her to use a taxi when covering news stories at night. The correspondent did not own a motorcycle and her boss was worried about her.

A dramatic situation once occurred when a resource person was quite aggressive in approaching a female journalist. Instantly, all her male journalist colleagues went to the informant's office and asked him 
to respect the female journalist. When such a situation occurs on a less dramatic scale, the female journalist's superior is usually open to receiving reports and will take action immediately.

What is interesting to note is that female journalists tended to receive more respect than their fellow male journalists when they achieved something that was considered professionally meaningful. For example, some male reporters we met had a name for one female journalist that they always recalled deeply. They admired her because she was very reliable when digging for news from sources that were considered difficult. Another example was a senior male editor who remembered some of the journalists he has trained, and he remembered them with respect.

Male journalists did not earn the same respect despite having similar achievements. This respect seemed to be inseparable from the perception that female journalists had to overcome more challenges to obtain their position. Women who tend to be silent and passive will not make good journalists. They have to be prepared to compete in a fierce field with male journalists who have many definite advantages.

Therefore, when female journalists occupy a strategic position on the editorial desk, or are in charge of male journalists, they tend to have an image that recognizes their ability in their field but eliminates their feminine qualities, which inspires male journalists to respect them. The respect female journalists received from their colleagues, and men's perceptions of women's editors seemed reasonable, considering women cannot do their work while being objects of beauty as their defining feminine feature. One prominent analogy was the association of female editors with fierce mothers.

\section{Results}

According to this presentation, how are global trends reflected in the real situation of journalists in Indonesia? How do gender distinctions operate when journalists work in their professional domain? One interesting point for discussion is that gender is not a free value concept. It has a master narrative that prevents it from slipping and becoming a completely disorganized narrative. We have learned that gender discourse has mutated and responded to the working situations faced by female journalists when fulfilling their duties. Here we discovered how the ideology of gender distinctions between men and women contributes to journalists' embodiment and maintains women in minority positions in the media world.

However, patriarchal ideology does not necessarily dispel one group from a more powerful or strategic position than the other. It operates through the demands made of women external to the working environment, as well as inside women themselves, where media work is portrayed as a masculine job. The minority position of women in the media is due to fewer female journalists, and this cannot be separated from wider public expectations of women, which is distinct from the availability of opportunities for women to work in the media.

Interestingly, this gender distinction seems to help female journalists gain the respect of their male colleagues. Female journalists are understood to face greater challenges and must transcend their feminine character if they want to be someone who succeeds in this field. As a result, they have a greater struggle when competing to become a respected journalist. At the same time however, the assumption that female journalists have limitations and are vulnerable to being treated as objects leads male journalists to protect them.

\section{Conclusions}

Essentially, we found that gender distinctions continue to operate using the same dichotomies. Women tend to be treated as objects who belong in the domestic domain, while men are the opposite. However, in their daily professional context as journalists in Indonesia, this separation seems to help them to succeed, at least among their colleagues. Nevertheless, this study focused on working conditions in Indonesia only, where the number of female journalists remains relatively small. These conditions are of course very different to a context where the number of female journalists may be considered a serious threat to male journalists.

\section{References}

Berger, J. (1972). Ways of Seeing. London: Penguin Books.

Butler, J. (1990). "Performative Acts and Gender Constitution: An Essay in Phenomenology and Feminist Theory." Performing Feminisms: Feminist Critical Theory and Theatre. Ed. Sue-Ellen Case. Baltimore: Johns Hopkins UP. 
Byerly, C. M. (2013). Introduction. Dalam Byerly, Carolyn M. (peny.) The Palgrave International Handbook of Women and Journalism. London: Palgrave Macmillan.

Caraway, T. (2007). Assembling Women: The Feminization of Global Manufacturing. Ithaca: Cornell University Press. Chambers, Deborah dkk. 2004. Women and Journalism. London: Routledge.

Comaroff, J., \& Comaroff, J. L. (Eds.). (2001). Millennial capitalism and the culture of neoliberalism. Duke University Press.

Mann, K. (1996). Tribal Women: On the Threshold of Twenty-first Century.New Delhi: M D Publications. Mulvey, Laura. 1975. Visual Pleasure and the Narrative Cinema. Screen Oxford Journals

Rosaldo, M. Z., Lamphere, L., \& Bamberger, J. (1974). Woman, Culture, and Society. California: Standford University Press.

Ross, K. (2001). Women at work: Journalism as engendered practice. Journalism Practices

Tusan, M. E. (2005). Women Making News: Gender and Journalism in Modern Britain. Urbana: University of Illinois Press. 